\title{
静水中に瞬間的に投下された濁水塊の底面衝突 後の挙動に関する実験的研究 \\ EXPERIMENTAL STUDY ON THE MOTION OF TURBIDITY CLOUDS PRODUCED IN A STAGNANT WATER
}

\author{
秋山 壽一郎 $^{1} \cdot$ 浦 勝 $^{2} \cdot$ 応 新亜 $^{3} \cdot$ 井手野 創 $^{4} \cdot$ 中西 弥生 ${ }^{4}$ \\ Juichiro AKIYAMA, Masaru URA, Xinya YING, Hajime IDENO and Yayoi NAKANISHI \\ ${ }^{1}$ 正会員 Ph.D. 九州工業大学助教授 工学部建設社会工学科 （广804-8550北九州市戸畑区仙水町1-1） \\ ${ }^{2}$ 正会員 工博 九州工業大学教授 工学部建設社会工学科 (同上) \\ 3学生員 工修 九州工業大学大学院 工学研究科博士後期課程 (同上) \\ 4学生員 九州工業大学大学院 工学研究科博士前期課程 (同上)
}

\begin{abstract}
Motion of turbidity clouds propagating along the bottom boundary, that produced by instantaneous release of turbid water from water surface into a stagnant water, is investigated experimentally. A series of laboratory experiments is conducted by varying inflow condition as well as ambient water depth. The motion of turbidity clouds is found to be distinguishied into two flow regions: the transition and gravity current region. The effects of inflow condition and ambient water depth on the motion of the clouds, and the relationships of the flow characteristics before and after impingement are investigated.
\end{abstract}

Key Words : turbidity, gravity current, turbulent thermal, water pollution, experiment

\section{1. はじめに}

海上空港などの建設を目的とした土砂直投工では、 微細土粒子を含む多量の土砂が水面付近から投入さ れるため、大規模な污濁が発生し水産資源をはじめ とする水生生物に甚大な被害をもたらすことが大き な問題である。その際の具体的な污濁拡散防止対策 として、水表面近くの濁質拡散防止之微細粒子の沈 降促進のための「懸垂型污濁防止膜」と底面近くの 濁質拡散防止のための「自立型污濁防止膜」が、単 体あるいはそれらの組久合わせとして広く用いられ ている。污濁防止膜は濁質拡散防止の効果的な手段 であるが、その有効性が必ずしも認められない事例 が報告されている。例えば、底面に衝突した濁水塊 が底面に沿って流動し、短時間の間に広範囲な污濁 を引き起こす要因となることを指摘した古土井 ${ }^{1)}$ の 観測結果などはその一例である。

防止膜の展張およびその配置については今のとこ ろ経験的に決定されているのが実情であり、その合 理的な展張・配置方法の確立が強く望まれている。 そのためには、投下土砂の落下挙動とそれに伴う誘 起流動のみならず、衝突後、底面に沿って流動する 濁水塊の挙動に関する基礎的理解が不可欠である。
なぜならば、潮流やそれによる自立型防止膜の著し い変形がない状況では、自立型防止膜の設置高さよ り低い層厚の流動層が防止膜を乗り越え流動・拡散 するとは考えられず、その設置高さを濁水塊の最大 層厚よりも高くすることが污濁拡散防止のための一 つの目安となると推察されるからである。

投下土砂あるいは濁水塊の落下特性については、 サーマル理論 ${ }^{2 \sim 4)}$ や数值シミュレーション ${ }^{b-8)}$ を通じ てかなりの程度まで明らかにされている。しかしな がら、その底面衝突後の挙動については、投棄土砂

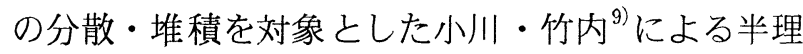
論的研究、投下量と周囲水水深を変化させ中央粒径 が $3.38 \mathrm{~mm}$ と $0.15 \mathrm{~mm}$ の 2 種類の砂を直投した実験 研究とサーマル理論に基づく理論解析より底面衝突 後の粒子群の流動特性に関する基礎的な理解と理論 予測を行った玉井らの研究 ${ }^{10)}$ 、混相 $\mathrm{k}-\varepsilon$ モデルに 基づく数值シミュレーションにより污濁の初期拡散 を定性的に検討しようと試みた玉井ら ${ }^{11)}$ の研究、あ

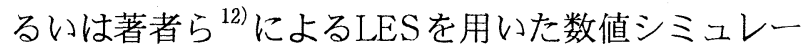
ションに基づく研究などがある。しかし、投下量や 周囲水水深が衝突後の濁水塊の挙動にどのような影 響を与えるのかといった基本的な点について十分な 
理解が得られているわけではない。

本研究は、そのような立場から、土砂直投により 発生する落下濁水塊の流動特性とその底面衝突後の 底面に沿う流動層の流動特性との関係について基礎 的な知見を得ることを試夕たものである。ここでは、 微細粒子による污濁拡散を想定し、流入条件および 周囲水水深と濁水塊の底面衝突前後の特性との関係、 および衝突後の底面沿って流動する濁水塊の流動特 性との関係について実験的に検討を加える。

\section{2. 実験}

実験装置は長さ $7.5 \mathrm{~m}$ 、深さ $1.0 \mathrm{~m}$ 、幅 $0.1 \mathrm{~m}$ の両 面アクリル製の水槽であり、水深hの静水中に擋汼 装置を取付けた流入装置から初期総浮力 $2 W_{0} \quad(=2$ $\left.\varepsilon_{0} \mathrm{gA}_{0}\right)$ の濁水を瞬間的に直投することによって落 下濁水塊を発生させた。ここに、 $A_{0}=$ 単位幅当り濁 水の投入量、 $\varepsilon_{0}=$ 濁水の相対密度差 $\left(=\left(\rho_{0}-\rho_{\mathrm{a}}\right) /\right.$ $\left.\rho_{\mathrm{a}}\right) 、 \rho_{0}=$ 投下濁水密度、 $\rho_{\mathrm{a}}=$ 周囲水密度および $\mathrm{g}=$ 重力加速度である。濁質としてはガラスビーズ (中央粒径 $\mathrm{d}=0.0044 \mathrm{~cm}$ 、粒子の水中比重 $\mathrm{s}=1.467$ ) を用いた。ガラスビ一ズだけではなく濁水として投 入した理由はガラスビーズのタを投下した場合では 十分に分散した落下濁水塊を形成することが困難で あったためである。なお、粒子だけを直投した場合 の $\mathrm{W}_{0}$ はW $=\mathrm{sgA}_{0}{ }^{\prime}$ で与えられる。ここに、 $\mathrm{A}_{0}{ }^{\prime}=$ 空隙 を除いた粒子の夕の初期単位幅体積である。実験は 投下量を 3 通り、水深を 2 通りに変化させ行った。 実験条件を表- 1 に示す。なお、現象は落下濁水塊 の中心軸に対して左右対称であるので、その右側だ けを解析の対象とした。徉って、全投下量の半分が W。である。

CASEA-3とCASEB-3の濁水塊の流動状況を図1 に示す。CASEAとCASEB とでは水深が異なるが、 いずれの場合も落下中に形成されたほぼ左右対称の 循環流より構成される濁水塊が底面衝突前に左右に 分離し、濁水塊はその形状を縦長の楕円形状から 1/4棈円形状へと変化しながら底面に沿って流動す るが、浮遊粒子が沈降堆積するため最終的には濁水 塊は消隇する。

実験方法は以下の通りである。落下濁水塊とそ の底面衝突後の水平流動する濁水塊の流動状況を CCDカメラで撮影し、コンピュター制御が可能な VTRに収録された画像を解析することにより、濁 水塊の落下速度 $\mathrm{V}$ と水平流動濁水塊の最先端部の移 動速度Ufおよびそれぞれの形状を求めた。流れの 再現性は必ずしも良好ではなかったので、同一条件 下で繰り返し実験を行い、ほぼ左右対称に分離した と認められるデータを 5 セット得た。
表-1 実験条件

\begin{tabular}{|c|c|c|c|c|c|}
\hline & $\begin{array}{r}\begin{array}{c}\text { 永深 } \\
\mathrm{h}(\mathrm{cm})\end{array} \\
\end{array}$ & $\begin{array}{c}\text { 相対蜜度差 } \\
\varepsilon_{0}\end{array}$ & $\begin{array}{l}\text { 濃度 } \\
\text { c(\%) }\end{array}$ & $\begin{array}{c}\text { 初期単位幅体積 } \\
2 \mathrm{~A}_{0}\left(\mathrm{~cm}^{2}\right)\end{array}$ & $\begin{array}{l}\text { 初期総浮力 } \\
2 \mathrm{~W}_{0}\left(\mathrm{~cm} / \mathrm{s}^{2}\right)\end{array}$ \\
\hline CASE & \multirow{3}{*}{50} & 0.24 & 16.1 & 25.0 & 5800 \\
\hline CASEA-2 & & 0.24 & $\overline{16.3}$ & 41.8 & 9800 \\
\hline CASEA-3 & & 0.29 & 19.9 & 48.0 & 13720 \\
\hline CASEB-1 & \multirow{3}{*}{90} & 0.24 & 16.1 & 25.0 & 5800 \\
\hline CASEB-2 & & 0.24 & 16.3 & 41.8 & 9800 \\
\hline CASEB-3 & & 0.29 & 19.9 & 48.0 & 13720 \\
\hline
\end{tabular}

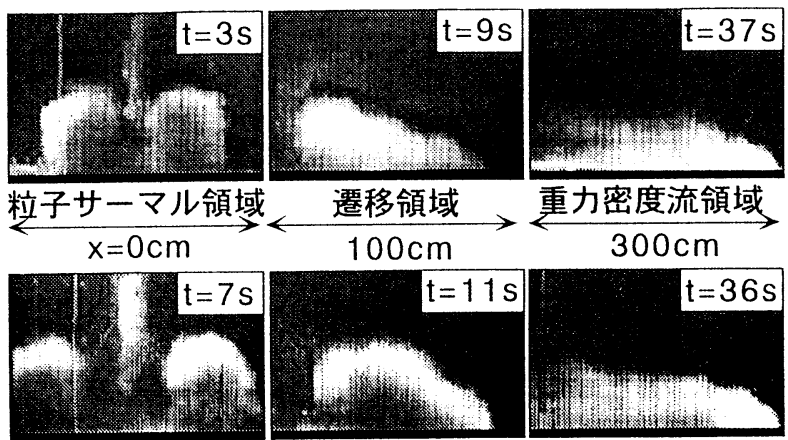

図-1 流動状況図（上:CASEA、下:CASEB）

また、底面に沿つて水平流動する濁水塊の総浮力 Wの保存状況あるいは粒子の堆積状況を調べる目的 で、濁水塊が通過した瞬間に所定の断面に設置され た仕切りゲートをすばやく降ろし、仕切りゲートを 隔てて左右に底面に堆積した粒子を丁寧に採集し、 その乾燥重量を求めることで浮遊粒子量 $\mathrm{W}_{\mathrm{s}}$ と堆積 量W $W_{d}$ 算定した。その際、同一条件下で繰り返し 実験を行い、落下濁水塊がほぼ左右対称となった場 合の斥仕切りゲートを用いた実験を実施した。ただ し、見掛け上はほぼ左右対称であっても必ずしも濁 水塊の全投下量 $2 W_{0}$ が左右均等に分離されるわけで はないので、落下濁水塊の中心軸から右側ひ堆積量 がW。の95\%以上のものを良好なデ一タとして採用 した。対象とする流れは一過性の現象であるので、 仕切りゲートの設置位置を流下方向に移動させ、流 下方向の $W_{s}$ とW $W_{d}$ の分布形状をそれぞれ 3 セット得 た。

\section{3. 実験結果}

図- 1 から明らかなように、濁水塊の落下挙動は ほぼ左右対称の循環流より構成される濁水塊が周囲 流体を連行しながら粒子サーマル的に落下する。底 面衝突後は左右に分離した濁水塊が縦長の棈円形か らほぼ1/4棈円形状に変形しながら水平流動する。 さらに、投下点からある程度離れたところでは濁水 塊はほぼ1/4棈円形状を保ちながら密度流として水 平流動するが、浮遊粒子の沈降堆積にともない最終 


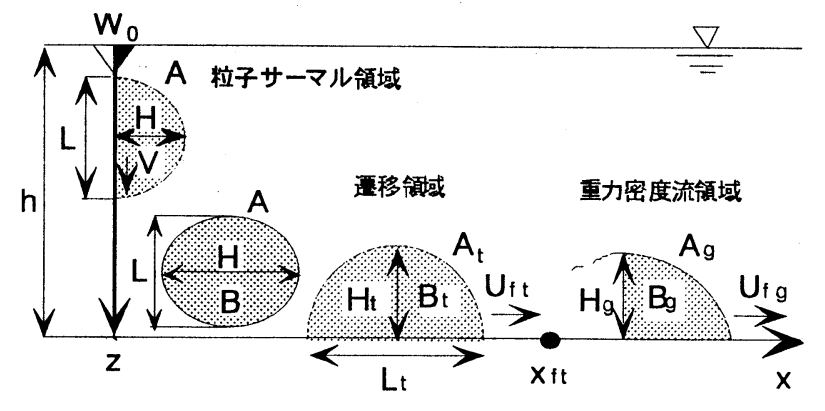

図-2 流れの定義図

的に消滅する。このような一連の濁水塊の挙動は、 本研究より粒径が大きな粒子を用いた玉井ら ${ }^{10)}$ の実 験結果とほぼ同様であり、また、粒子の沈降堆積に よる消滅プロセスを除けば、基本的に直投塩水塊の 挙動とも同じである ${ }^{13)}$ 。

このような観測結果に基づき、直投濁水塊の流動 状況を粒子サーマル領域、サーマルから重力密度流 への遷移領域および重力密度流領域の 3 領域に区分 し、濁水塊の主要な流動特性量を図- 2 のように定 義する。なお、図一 2 において、Aは底面衝突直前 の左右に分離した状態の濁水塊の単位幅体積、L、 HおよびBはそれぞれその状態における最大高さ、 最大広がり幅および平均浮力である。また、図中の $\mathrm{x}_{\mathrm{t}}$ は遷移領域から重力密度流領域への遷移点である。 なお、サーマル領域における濁水塊の落下挙動につ いては参考文献 ${ }^{14)}$ 通じて明らかにされているので、 ここでは底面衝突前後および衝突後の濁水塊の挙動 について検討を加える。

まず、底面衝突後の濁水塊の単位幅体積A、最大 高さH、長さL、断面アスペクト比 $F(=H / L) 、$ 先端 移動速度 $U_{f}$ および平均浮力 $\mathrm{B}(=\varepsilon \mathrm{g})$ と流下距離 $\mathrm{X}_{\mathrm{f}}$ と の関係について検討する。投下粒子の粒径が一定の 実験条件下では、底面衝突後の濁水塊の流動特性は 投入条件 $\left(\mathrm{A}_{0} 、 \mathrm{~W}_{0}\right)$ と周囲水水深hに支配されると考 えられる。従って、FとU $\mathrm{f}$ を除くいずれの特性量も A 0 あるいはhで無次元化されている。ただし、Bに ついては両者の組合わせで無次元化されている。図 中の@などにダッシュ付きで示したものがhを考慮 して無次元化した特性量である。サーマル理論 ${ }^{4)} に$ よれば、HとLは落下距離乙に線形的に増加するので、 底面衝突直前のAはhの2乗に比例すると考えられる。 同様な理由でBはZの-2乗に比例するので hとW。を 用いれば、代表的な平均浮力のスケールとしては $\mathrm{W}_{0} / \mathrm{h}^{2}$ が得られる。図- 3 から明らかなように、遷 移領域ではんに対する明瞭な依存性が認められるも のの、重力密度流領域では $\mathrm{A}_{0}$ に対する依存性の方が 明らかに強いことがわかる。この理由は、重力密度 流領域における濁水塊の幾何学的形状は濁質の総量、 つまりW。に規定されるためであると考えられる。 ただし、Bについては明らかにW $\mathrm{W}_{0} / \mathrm{h}^{2}$ に依存してい

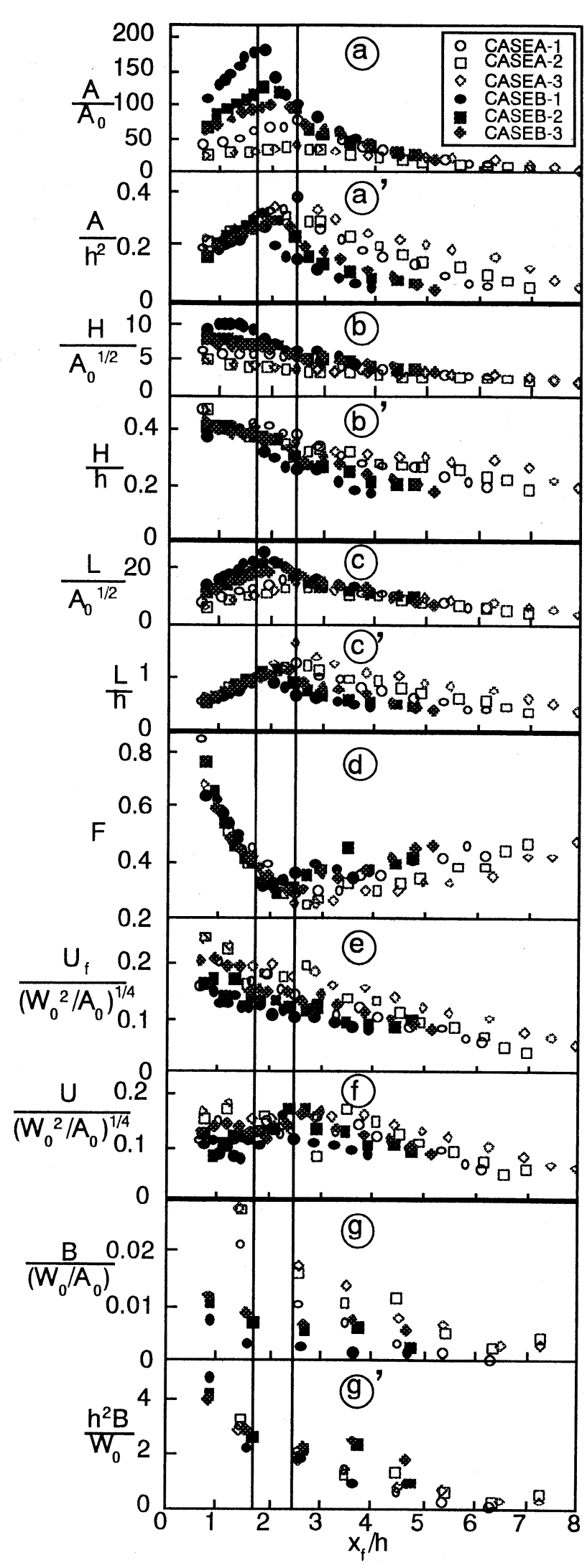

図-3 流動特性量と無次元流下距離 $\mathrm{x}_{\mathrm{f}} / \mathrm{h}$ との関係 (a: 無次元断面面積、 b: 無次元最大高さ、c: 無次 元長さ、 d: 断面アスペクト比、e: 無次元先端移動 速度、 $f$ :無次元重心移動速度、 $g$ :無次元平均浮力） 
る。

本研究の目的からすると重力密度流領域の方が遷 移領域より重要であるので、以下では、 $\mathrm{A}_{0}$ に対する 依存性について検討を加える。また、流下距離神 水深hで無次元化されている。図- 3 aより、無次元 断面面積 $\mathrm{A} / \mathrm{A}_{0}$ は流下方向にまず増加し、その後徐々 に減少する傾向が全てのCASEで認められるが、そ の值と増加量は投下量 $\mathrm{W}_{0}$ が小さいほど大きく、周 囲水水深hが大きいほど大きい。また、投下量が CASE 1、2、3で大きく変化しているにもかかわ らず、 $\mathrm{W}_{0}$ とhの影響を強く受けることがわかる。ま た、観測結果より、この増加から減少に点ずる位置 は遷移領域加重力密度流領域への遷移点 $\left(\mathrm{x}_{\mathrm{ft}}\right)$ とほ ぼ一致していることが認められた。なお、遷移点の 位置はCASEA $て \mathrm{x}_{\mathrm{ft}} / \mathrm{h} \fallingdotseq 2.40 、$ CASEB $て \mathrm{x} \mathrm{ft}_{\mathrm{ft}} / \mathrm{h} \fallingdotseq$ 1.90 で近似できる。図- $3 \mathrm{~b}$ より、無次元最大高さ $\mathrm{H} / \mathrm{A}_{0}{ }^{1 / 2}$ は全てのCASEにおいて流下方向に減少す る傾向が認められるが、その值はW。が小さいほど 大きく、hが大きいほど大きい。また、CASEAで は $\mathrm{x}_{\mathrm{ft}}$ を境に著しく傾向が変化することはないが、 CASEBではそのような傾向が伺われる。図-3cよ り、無次元長さ $\mathrm{L} / \mathrm{A}_{0}{ }^{1 / 2}$ は流下方向にまず増加し、 その後徐々に減少する傾向が全てのCASEで認めら れ、その増加量は $\mathrm{W}_{0}$ が小さいほど大きく、hが大き いほど大きい。また、 $\mathrm{W}_{0}$ の変化にもかかわらず、 $\mathrm{x}_{\mathrm{ft}}$ の值はW $\mathrm{W}_{0}$ にさほど依存しないが、水深の影響を 強く受ける。このような傾向と遷移点の位置はA/ $\mathrm{A}_{0}$ とほぼ同様である。さらに图- 3dより、断面アス ペクト比Fは流下方向にまず大きく減少し、その後 徐々に増加する傾向が全てのCASEで認められ、そ の傾向はhにはやや依存しているが、鹿ははほとんど 依存していないことがわかる。加えて、Fが減少か ら増加へと転じる位置は $\mathrm{A} / \mathrm{A}_{0}$ とL $/ \mathrm{A}_{0}{ }^{1 / 2}$ の場合とよ く一致している。無次元先端移動速度 $U_{\mathrm{f}} /\left(\mathrm{W}_{0}{ }^{2} /\right.$ $\left.\mathrm{A}_{0}\right)^{1 / 4}$ は図- 3eより、 $\mathrm{x}_{\mathrm{ft}}$ の前後で傾向の違いが若干 見られるものの、全てのCASEにおいて流下方向に 緩やかに減少する傾向が認められ、その值はW あまり依存せず、hが小さい方が大きい。図-3fの 重心移動速度では見られないhに対する依存性が先 端移動速度でやや強く認められる理由としては、濁 水塊内外の圧力差によるスランピングが水深の小さ なCASEAでより強いためであると考えられる。ま た、当然のことながら、重心移動速度よりも先端移 動速度の方がスランピングの影響が大きいことから、

図-3eと図-3fとに見られる $\mathrm{x}_{\mathrm{f}} / \mathrm{h}$ に対する傾向の違 いも説明される。図-3gより、無次元平均浮力 $\mathrm{B} /$ $\left(\mathrm{W}_{0} / \mathrm{A}_{0}\right)$ はW $\mathrm{W}_{0}$ とhのいずれに対しても依存し、平均 浮力Bについてはややばらつきは認められるものの、

遷移領域および重力密度流領域ともにパラメータ $h^{2} \mathrm{~B} / \mathrm{W}_{0}$ で良く表現でき、流下方向に減少する傾向

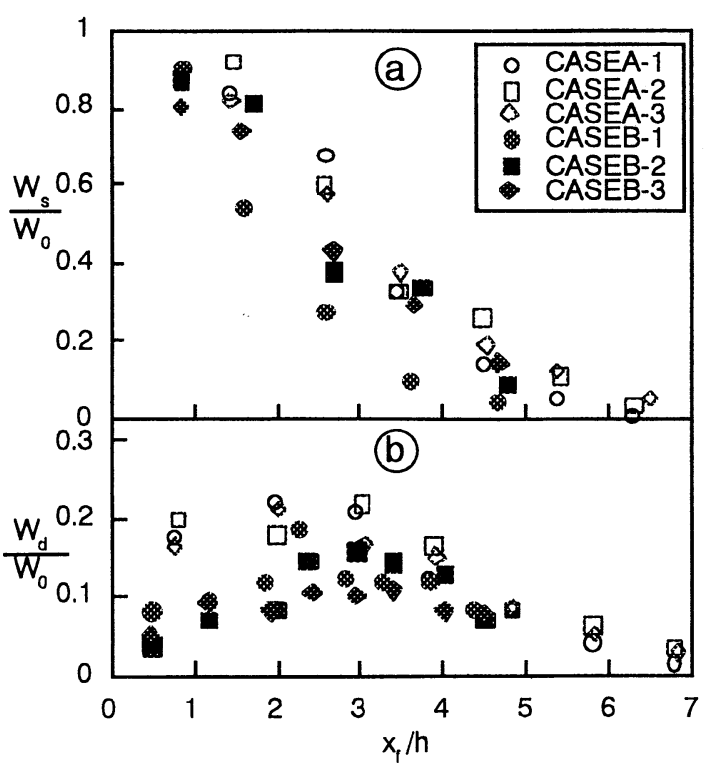

図-4 濁水塊の浮遊粒子量 $\mathrm{W}_{\mathrm{s}}$ および堆積量 $\mathrm{W}_{\mathrm{d}}$ と無次元 流下距離 $\mathrm{x}_{\mathrm{f}} / \mathrm{h}$ との関係 $\left(\mathrm{a}: \mathrm{W}_{\mathrm{s}} 、 \mathrm{~b}: \mathrm{W}_{\mathrm{d}}\right)$

がある。

以上を総括すると、底面衝突後の濁水塊の挙動 は、遷移領域および重力密度流領域の2領域に区分 され、程度の違いは認められるものの各領域の流動 特性は異なった傾向を持つ。底面衝突直後から重力 密度流領域のある点 $\left(\right.$ 本研究では、 $\left.\mathrm{x}_{\mathrm{f}} / \mathrm{h} \fallingdotseq 4.0\right)$ まで の濁水塊の挙動は投下条件と周囲水水深に支配され、 その影響は特性量によって大きく異なるが、 $\mathrm{x}_{\mathrm{f}} / \mathrm{h}$ が それ以上大きい重力密度流領域では後者の影響をほ とんど受けない。一方、遷移領域は前者の影響を強 く受けることなどがわかる。

次に、水平流動する濁水塊の浮遊粒子量 $\mathrm{W}_{\mathrm{s}}$ と堆 積量W $\mathrm{W}_{\mathrm{d}}$ の分布形状を示したものがそれぞれ図-4a と4bである。なお、図中の值ははいずれも 3 セッ トのデータの平均値をプロットしたものであるが、 繰り返し実験による值の若干のばらつきは認められ たものの、 $\mathrm{W}_{\mathrm{s}}$ とW $\mathrm{W}_{\mathrm{d}}$ に関する全てのデータの標準偏 差はそれぞれ 0.025 と0.027程度であり、平均値を 求める上で支障のない程度のばらつきであった。図 - 4aより、W $\mathrm{W}_{\mathrm{s}}$ はW $\mathrm{W}_{0}$ とhのいずれに対しても強い依存 性を持たず、流下方向に一律に減少する。一方、 $\mathrm{W}_{\mathrm{d}}$ はW $\mathrm{W}_{0}$ に対する傾向的な依存性は認められないも のの、その分布形状は $\mathrm{h} に$ 強く依存している。 CASEAに比してCASEBでは、投下点近くの堆積量 が少なく、またそこでの堆積量の増加率が大きい。 このような分布形状の違いは、落下濁水塊の挙動に 起因すると考元られる。つまり、CASEBに比して CASEAでは水深が小さいため、発達した乱流サー マルが形成されず、乱れが弱いため投下点近くで粒 子の沈降堆積が生じるが、水深が大きなCASEBで は図-1 からも明らかなように、落下濁水塊は底面 


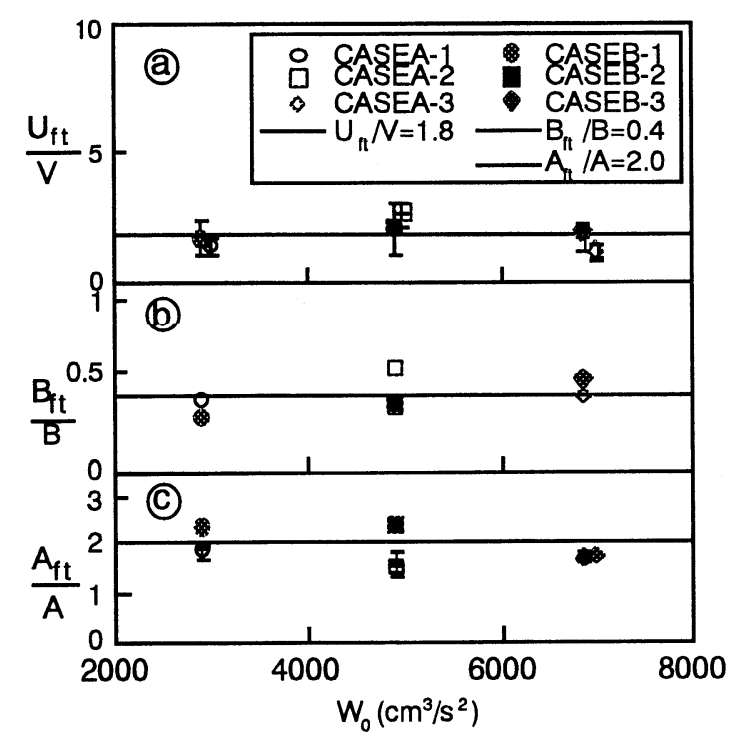

図-5 衝突前後の流動特性量の関係( $(\mathrm{a}$ :速度比、b:平均 浮力比、 c:断面面積比)

衝突以前に左右の濁水塊が分離する。その結果、濁 水塊が投下点からやや離れた位置で底面に衝突し、 そのような状態で粒子の沈降堆積が起こるためであ ると考えられる。

次に、底面衝突前後の流動特性量について検討す る。投入点において与えられた流入条件から、衝突 後に底面に沿って流動する濁水塊の挙動を知るため には、底面衝突前後の濁水塊の流動特性を明らかに する必要がある。そこで、衝突直前の落下特性量と 遷移点 $\mathrm{x}_{\mathrm{ft}}$ における重力密度流領域の特性量との関係 について調べたものが図-5である。図中の記号は 各W。に対して5データの平均値であり、各記号に付 加した矢印は標淮偏差を示す。図- 5 aより、 $\mathrm{x}_{\mathrm{ft}}$ にお ける濁水塊の先端移動速度 $\mathrm{U}_{\mathrm{ft}}$ は衝突直前の落下速 度Vに比べかなり増加している。図-3eで見たよう にU $\mathrm{f}_{\mathrm{f}}$ 流下方向に単調に減少することを勘案すると、 小川・竹内 ${ }^{9)}$ や玉井ら ${ }^{10)}$ の理論解析で仮定された衝 突前後の速度比 $U_{f} / V=1.0$ なる関係は必ずしも妥当 でないことが確認できる。また、ばらつきは認めら れるものの、速度比 $\mathrm{U}_{\mathrm{ft}} / \mathrm{V}$ は $\mathrm{W}_{0}$ やhに傾向的に強く 依存することはなく、ほぼ一定值 $(=1.80)$ を取るよ うである。图- $5 \mathrm{~b}$ は、 $\mathrm{x}_{\mathrm{ft}}$ における濁水塊の平均浮力 $\mathrm{B}_{\mathrm{ft}}$ と衝突直前の落下濁水塊の $\mathrm{B}$ との関係について調 べたものである。浮力比 $\mathrm{B}_{\mathrm{ft}} / \mathrm{B}$ は $\mathrm{W}_{0}$ が増加するとわ ずかながら増加する傾向が存在するようであるが、 データのばらつきを考慮するとW $\mathrm{W}_{0}$ への傾向性は無 いと考えるのが妥当であろう。つまり、浮力比 $\mathrm{B}_{\mathrm{ft}}$ / BはW。やhに傾向的に強く依存することはなく、ほ ぼ一定值 $(=0.40)$ を取るようである。なお、 $\mathrm{B}_{\mathrm{ft}}$ は仕 切りゲートを用いて得られた濁水塊の総浮力 $\mathrm{W}_{s}$ を 画像解析より求められた濁水塊の断面積Aで除する ことによって算定している。図-5c は、断面面積比

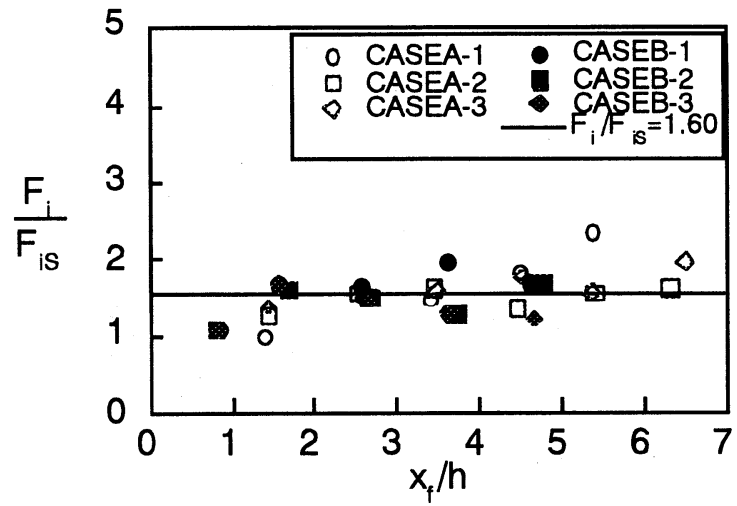

図-6 $\quad \mathrm{F}_{\mathrm{i}} / \mathrm{F}_{\mathrm{lS}}$ と $\mathrm{x}_{\mathrm{f}} / \mathrm{h}$ との関係

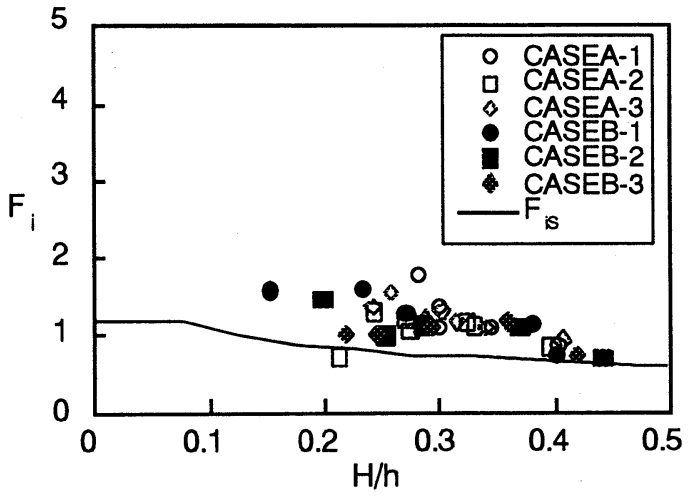

図-7 $\quad \mathrm{F}_{\mathrm{i}}$ とH/hとの関係

$\mathrm{A}_{\mathrm{ft}} / \mathrm{A}$ について調べたものであるが、これもW。やh に傾向的に強く依存することはなく、ほぼ一定值(= 2.0)を取るようである。

最後に、重力密度流領域の濁水塊の内部Froude 数F,について検討を加える。重力密度流領域の濁水 塊の挙動は、水平面上の有限な重い流体を瞬間的に 解放することによって生じる通常の重力密度流と類 似した特性を持つと期待される。Huppert \& Simpson ${ }^{15)}$ は多くの塩水重力密度流の実験デー夕に 基き、塩水重力密度流の内部Froude数 $\mathrm{F}_{\mathrm{is}}$ が周囲水 水深hと流動層厚 $\mathrm{H}$ との比である相対層厚 $\mathrm{H} / \mathrm{h}$ によっ て変化し、次式でその関係を与えている。ここで、 $\mathrm{F}_{\mathrm{i}}$ と $\mathrm{F}_{\mathrm{iS}}$ のいずれもは $\mathrm{U}_{\mathrm{f}} /\left(\mathrm{B}_{\mathrm{g}} \mathrm{H}\right)^{1 / 2}$ で定義される内部 Froude数である。

$$
\begin{gathered}
\mathrm{F}_{\text {is }}=1.19 \text { for } \mathrm{H} / \mathrm{h} \leqq 0.075 \\
\mathrm{~F}_{\text {is }}=0.5(\mathrm{H} / \mathrm{h})^{-\frac{1}{3}} \text { for } \mathrm{H} / \mathrm{h}=0.075 \sim 1.0
\end{gathered}
$$

図- 6 は重力密度流領域における濁水塊の内部 Froude数之塩水重力密度流との比 $\mathrm{F}_{\mathrm{i}} / \mathrm{F}_{\mathrm{iS}}$ の流下方向 変化について調べたものである。同図より、図- 3 で見たのと同様に遷移点 $\mathrm{x}_{\mathrm{ft}}$ で $\mathrm{F}_{\mathrm{i}}$ の傾向が変化してい ること、 $\mathrm{W}_{0}$ やhに傾向的に強く依存することはない こと、投下量の少ないCASEA-1では浮遊粒子量の 沈降堆積のため $\mathrm{x}_{\mathrm{f}} / \mathrm{h}$ が大きくなると $\mathrm{F}_{\mathrm{i}}$ が急增するこ 
と、CASEA-1を除く他のCASEではx $\mathrm{f}_{\mathrm{f}} / \mathrm{h} \fallingdotseq 1.9 \sim 4.0$ で $\mathrm{F}_{1} / \mathrm{F}_{\mathrm{iS}} \fallingdotseq 1.60$ のほぼ一定値を取ること、などがわ かる。特に、最後の点は重要で、 $\mathrm{x}_{\mathrm{f}} / \mathrm{h}=1.9 \sim 4.0$ の 範囲では活発に粒子を浮遊させながら重力密度流的 に流動することが流れの観測結果で認められており、 そのような状態では内部Fro ude 数が流下方向に一 定に保たれるものと考えられる。図一 7 はF, と相対 層厚 $\mathrm{H} / \mathrm{h}$ との関係について調べたものである。これ より、全体的な傾向としては $\mathrm{F}_{\mathrm{i}}$ は $\mathrm{F}_{\mathrm{iS}}$ より約 1.60 倍程 度大きく、水平面上の塩水重力密度流と同様に $\mathrm{H} / \mathrm{h}$ が大きくなると減少する傾向があることが認められ る。ただし、なぜ $F_{i} / F_{i s} \fallingdotseq 1.60$ なる值を取るのかに ついては、直投濁水塊によって発生した重力密度流 的な濁水塊之通常の濁水重力密度流との流動特性の 違いを明らかにする必要があり、今後の重要な課題 である。

\section{4. まとめ}

（1）底面衝突後の水平流動する濁水塊の挙動は遷 移領域および重力密度流領域の2領域に区分され、 程度の違いは認められるものの各領域の流動特性は 異なった傾向を持つ。

（2） 底面衝突直後から重力密度流領域の $\mathrm{x}_{\mathrm{f}} / \mathrm{h} \fallingdotseq 4.0$ までの濁水塊の挙動は投下条件と周囲水水深に支配 され、遷移領域では水深、重力密度流領域では初期 総浮力に依存する。ただし、その影響は特性量によっ て異なる。また、 $\mathrm{x}_{\mathrm{f}} / \mathrm{h}>4.0$ では両者の影響をほと んど受けない。

（3）衝突直前の落下特性量と重力密度流領域の始 まりの点における特性量との関係は投下条件と周囲 水水深のいずれに対しても強く依存しない。

（4）重力密度流領域における濁水塊の内部Froude 数は粒子の沈降堆積に伴い変化するが、活発に粒子 を浮遊させながら進行する濁水塊の内部Froude数 は流下に際してほぼ一定に保たれる。

謝辟 : 本研究の一部は、文部省科学研究費 (代表者 : 秋山壽一郎、基盤研究 $\mathrm{B}(2)$ 、課題番号08455232) の援助を受けた。ここに記して感謝の意を表します。

\section{参考文献}

1）古土井光昭: 港湾工事における濁りの挙動に関する研 究, 大阪大学学位論文, 1989.

2) 玉井昌宏・村岡浩爾・室田明: 固体粒子群の落下挙動 と誘起流動に関する研究,土木学会論文集，No.509/ II -30, pp.143-154, 1995.

3) Buhler, J. and Papantoniou, D.A.: Swarms of coarse particles falling through a fluid, Proc. of the Int'l Symposium on Environmental Hydraulics, Vol.1, pp.135-140, 1991.
4）秋山壽一郎・浦 勝 - 応 新亜・今宮盛雄・陶山正 治: 静水中に瞬間的に投下された重たい流体塊の流動 特性に関す万研究，水工学論文集，第42巻，pp.529534, 1998.

5）堀江毅：MAC法による直投土砂の初期拡散に関する 数值解析, 運輸省港湾技術研究所技術資料, No.471, pp.1-34, 1983.

6) Li, C.W. : Convection of particle thermals, J. of Hydraulic Research, Vol.35, No.3, pp.363376,1997.

7）小田一紀・重松孝昌・大西伸幸・井上雅夫：改良型 DEMAC 法による粒子群の沈降・分散挙動の解析, 海岸工学論文集, 第39巻, pp.971-975, 1992.

8) Ying,X., Akiyama,J. , Ura,M. and Nakanishi,Y. : Large eddy simulation of heavy turbulent thermal, Annual J. of Hydraulic Engineering, Vol.43, pp.899-904,1999.

9）小川元・竹内益雄 : 土捨船による投裹土砂の分散, 土木学会論文集，第161号，pp.39-49、1969.

10）玉井昌宏・村岡浩爾・室田明・町田博紀: 土砂直投工 における濁りの初期拡散過程関する研究, 土木学会論文集，No.515/II-31，pp.77-86，1995.

11）玉井昌宏・村岡浩爾: 土砂直投工により発生する濁り の挙動特性に関する数値解析, 水工学論文集, 第42巻, pp.541-546, 1998.

12) Ying.X., Akiyama,J. and Ura,M.: Motion of dense fluid released into quiescent water with finite depth, 土木学会論文集(in press).

13）秋山壽一郎・浦 勝 - 応 新亜・中西弥生: 静水中に 瞬間的に投下された重い流体塊の底面衝突後の挙動, 水工学論文集, 第43巻, pp.1115-1120,1999.

14）秋山壽一郎・浦 勝・応 新要・西森秀樹: 静水・流 水中に瞬間的に投下された粒子群の流動特性, 水工学論文集, 第43巻, pp.905-910, 1999.

15) Huppert, H.E. and Simpson, J.E.: The slumping of gravity current, J. of Fluid Mechanics, Vol.99, pp.785-799, 1980.

(1999. 9. 30 受付) 